\title{
Faculty Development of Business Educators to Facilitate Students' Employment
}

\author{
*Mahmoud Yousef Askari \\ Al Ain University of Science and Technology, UAE
}

*mahmoud.askari@aau.ac.ae

\begin{abstract}
This paper highlights the needs of faculty development for business professors and sheds light on why business education is unique when compared to other disciplines. The paper argues that different disciplines should not be painted with the same faculty development brush when designing a development strategy. It also proposes that business professors, similar to other professors of applied fields, need to go through an industry experience as part of their faculty development process. Establishing the link between theory and practice is important for graduating business students which could shape their skills and facilitate their employment. The paper also proposes that one way to establish this link is through an applied pedagogical approach with the use of case studies to simulate real life situations.
\end{abstract}

Keywords: Faculty Development; Business Educators; Students Employment.

\section{Introduction}

Faculty development practices are not designed equally. Faculty members of different disciplines may require different development strategies. Some disciplines have their own unique link to the field of application like education and business, and other disciplines can hardly move beyond their theoretical frameworks such as history. This paper highlights the needs of faculty development at business schools based on an assumed goal of easy transition of students from classrooms to business organizations in the labor market. The paper argues that different disciplines should be treated differently when designing a faculty development strategy due to pedagogical differences of disciplines. The paper is divided into four sections. The first section is a review of literature. The second section presents the rationale for using different faculty development strategies for different disciplines. The third section discusses the uniqueness of business education. The fourth section presents an analysis of the faculty development approach at the Faculty of Management at an Ontario University (Laurentian).

\section{Literature Review}

Scholars define faculty development in different ways. Festervand and Tillery (2001) defined faculty development as "activities that promote the creation and transfer of knowledge" ( $p$. 109). According to Festervand and Tillery, the American Assembly of Collegiate Schools of Business defines professional faculty development as “... an ongoing process that includes such activities as participation in professional organizations, research and publication, continuing 
education, the acquisition of new and / or additional technical and discipline specific skill sets, and other enriching activities" (p. 106). According to Blignaut and Trollip (2003), learning how to teach online courses can be a key factor in defining faculty development. Legorreta, Kelley, and Sablynski (2006) stated that "faculty development in the broadest sense of the word encompasses teaching, research, career development, and personal health and growth" (p. 4). Alfano (1993) defined faculty development as "activities that colleges undertake to enhance individual or institutional capacities to teach and to serve students" (p. 68).

Legorreta et al. (2006) argued that transferring knowledge to students is insufficient anymore and academics need to show that students have acquired the needed skills to succeed in their careers. They also suggested that the importance of faculty development is driven by technological and demographic changes and by the demand for quality in higher education. Festervand and Tillery (2001) proposed that the participation of faculty members in an international development program can enhance teaching effectiveness. They explained that because of globalization, it is important to ensure that students are ready to deal with an international marketplace and therefore, faculty members need to have this international experience. Moreover, they believe that faculty members can gain considerable mental capacity by participating in a short international development program.

The shifting needs of community college students, according to Alfano (1993), usually trigger the orientation of faculty development programs, which focus mainly on cultural issues and on addressing the academic readiness of some students. Alfano added that faculty development programs are directed at full-time faculty and less attention is being paid to the needs of sessional and retiring faculty. She also summarized some strategies used in faculty development at American community colleges. Among these strategies are: (1) activities directed at students' needs;(2) linking the faculty's community colleges with universities for academic upgrade; (3) focussing on specific faculty needs, like the needs for part time instructors; (4) development programs to improve teaching skills; (5) producing a guide for faculty development; (6) development programs with a focus on promoting the curriculum; (7) linking faculty to industry to obtain industry experience; (8) encouraging scholarship and professionalism in the own disciplines of the faculty ; (9) tying development to faculty evaluation; and (10) allocating instructional days to be used for faculty development purposes.

\section{The Rationale for Using Different Development Strategies}

It could be argued that designing a faculty development strategy in an academic institution, based on a unified institutional objective, without considering differences in disciplines may not be the right approach. The needs of faculty members can widely differ based on the nature of their disciplines, differences among faculty members, and the intended professions of students after graduation. Lindblom-Ylänne et al. (2006) highlighted Becher's (1989) four categories of disciplines: (1) pure hard, (2) pure soft, (3) applied hard, and (4) applied soft, based on perceptions of culture and epistemology. According to Neumann and Becher (2002), hard disciplines are taught through lectures, simulations, and case studies, while soft disciplines are taught through debates and discussion tutorials. Lindblom-Ylänne et al. (2006) reported the 
same results and concluded that disciplines dictate the approach of teaching. They stated that "teachers from 'hard' disciplines were more likely to report a more teacher-focused approach to teaching, whereas those teaching 'soft' disciplines were more student-focused” (p. 294).

Lindblom-Ylänne et al. (2006) explained that in pure hard disciplines like Chemistry, teaching methods can be simple in the form of lectures, focusing on fact realization and problem solving. Pure soft disciplines, like History, are qualitative, requiring tutorial teaching methods through group discussions, and encouraging the generation and expression of ideas. In the applied hard disciplines (e.g. Business \& Medicine), the appropriate methods of teaching depend on the understanding and reproduction of case studies to imitate real life settings, with an emphasis on the application of theory and the development of students' capabilities. In the applied soft disciplines like Education, the emphasis is on the development of students' thinking skills.

Drawing the line between hard and soft, pure and applied disciplines can be the first step in designing a development strategy with a focus on the differences that exist between disciplines. Indeed, one might argue that because of these differences, development strategies need to be designed at the faculty level rather than at the institution level. Each faculty should know the needs of its members and should also consider age differences, experience levels, the nature of the industry/practice setting, and the needs of students. Painting all faculties with the same development brush may direct the scarce institutional resources, available for development purposes, to the wrong direction and may not yield the desired outcome. Thus, it is important to know the differences among disciplines when designing a faculty development strategy.

\section{The Uniqueness of Business Education}

The applied nature of business education and its link to industry can give a hint to faculty development needs. Knowledge of real life cases and industry experience can be a key requirement in the skill sets of business professors, regardless of their business specializations. Consequently, it could be argued that simulating real life cases in a classroom requires real life industry experience. Lacking the real touch of the profession in question may not help faculty members in their transmission of knowledge and in the facilitation of business education. Professors teaching philosophy, as an example, may not need to have real life industry exposure because philosophy does not belong to an applied "academic tribe" (Becher, 1989). However, it is desirable that professors teaching applied disciplines have a link to industry in order for that experience to be developed and then transmitted to students. It would be difficult for a painter to draw the right picture of something the painter has never seen, regardless of the painter's level of imagination. A theory in action can be seen in its real and actual face and not through its 'thought to be' image. A research participant in Askari's (2011) study, who received his business education degree from an Ontario university and works in a business organization, explained that teaching theories of business to students without an exposure to real life experience is insufficient. He stated that "they teach you the points and everything you need to know but they lack in the experience. They do not give that individual an experience. They throw a 22 year old into the world with very little to know experience" (p. 61). Gabrielsson, Tell, and Politis, (2010) explained that business schools usually teach the practice of leadership as a replacement of the development of students' skills to perform leadership. Indeed, one can argue that if professors 
of an applied discipline like business lack a real life experience, it might be hard for them to simulate a real life case to students.

In addition to the need to have a real life business experience, business faculty members need to master teaching and facilitation through case studies. According to Barnes, Christensen, and Hansen (1994), a case is a story of a real life business scenario faced by managers or leaders, and used in classrooms to stimulate students' thinking in crafting and implementing alternative solutions. According to Rippin, Booth, Bowie, and Jordan (2002), "The case method allowed aspiring managers to practice intervention skills in a safe environment." (p. 429). They explained that the objective of business education relies on training students for an occupation by building their critical thinking skills to solve problems and to make the right decisions. Rippin et al. (2002) also added that the case approach in business education is the most powerful method because it teaches students how to take action.

Developing the skills of business faculty members to master the case study as a pedagogical tool to teach business students and having a real life industry experience can be the target of a faculty development strategy. One can argue that these two faculty development needs are related due to their link to real life scenarios. Practicing the decision making process through case studies in a classroom may have more benefits to students than learning best practices. This real life simulation needs to be facilitated by a faculty member who has had a sense of real life practice. Relying on the theoretical knowledge of best practices may not help students connect to their intended destination. Weinzimmer and Manmadhan (2009) explained that there is a gap between theory and practice. In their efforts to study this gap, they measured the difference between business researchers' perception of success of small business, and business owners' perception of success. They found that the most frequent measures of success used in the relevant literature were financial measures, whereas the most frequent measures of success expressed by business practitioners were related to customer satisfaction.

Business schools can overcome the separation of theory and practice by facilitating faculty development programs that have some form of industry exposure. It can be argued that describing the fire is nothing like getting burned by its flames. It can be difficult to imagine how professors of medicine could adequately train medical students to treat patients without ever having to treat patients themselves. Similarly, it can be challenging for business professors to train students on how to manage companies without ever being in one. Some educators are also asserting that students need to have a taste of a real life experience to be prepared for their careers. Elkin (2006) explained that a real-world experience contains a wide range of incidences that people see during their life. He argued that "if you are going to learn to drive a car, isn't it better to get in one and drive it down the road?" (p. 13). If it is logical to assume that students themselves need some form of a real life experience to succeed, then one can argue that educators also need this experience.

Thus, one could assume that business schools need to have a focus on learning rather than on teaching. If the goal of business higher education is to produce ready to work, capable and talented business managers, then what counts is how ready students are to manage businesses 
when starting their careers. Moving beyond the teaching of concepts and theories and helping students in the transition to their careers by mastering the applied skills have substantial support in literature. Karmas (2011) explained that teachers play a significant role in the successful changeover of students from classrooms to the workplace by developing their life skills. Gabrielsson et al. (2010) stated that business schools are criticized due to disconnection between theory and practice and because of their dependence on analytical objectivity and their ignorance of real life business problems. This means that it is desirable to develop the skills of business faculty members themselves through a real life business experience and that those without this experience need to have the opportunity to develop this knowledge.

\section{Faculty Development at Laurentian University's Faculty of Management}

It can be challenging to trace faculty development programs by visiting the websites of some universities. In an exercise done in Dr. Patterson's Faculty Development class at Werklund School of Education, University of Calgary in the summer of 2012, a group of 10 doctoral students were unable to find descriptions of faculty development programs linked to many universities' websites. Only large universities with faculties of medicine reliably showed some programs of faculty development. Laurentian University's Faculty of Management Website. (n.d.) is similar to many other universities when searching for information related to faculty development. Searching for the words "faculty development" in the search area of the website yielded no results.

\section{Analysis}

To be fair to Laurentian University and other universities, there may be some faculty development programs that are taking place in different faculties of the university, including the Faculty of Management, but these programs are not disclosed. At least, according to Festervand and Tillery (2001), research is considered a form of faculty development and tenured faculty members are required to do research. It can be argued that conducting research can develop one's deeper knowledge of a certain discipline, which is a base requirement for a good faculty member. Nevertheless, one's knowledge of a certain discipline is only one leg of the faculty's development table. The ability to pass that knowledge on to students using the right pedagogical method can be the "Real McCoy" in the learning process. As Nonaka and Takeuchi (1995) explained, learning happens when transforming the tacit knowledge, which is in people's heads and is difficult to communicate, to explicit knowledge that is easy to communicate.

It was surprising to see that Laurentian's Faculty of Management mission statement has a clear hint of what skills are important for faculty development: "Our students are supported by faculty who are committed to quality and continuous improvement in teaching and advancement of management knowledge through an active program of research" (Laurentian University's Faculty of Management Website, n.d.). The website had no further explanation on how improvement in teaching is maintained, or how pedagogical training in management is conducted. Furthermore, there is no information on any mentorship development programs or on training for new, midcareer, or senior faculty members. It can be fair to assume that if such programs do exist, it would be in the best interest of the school to communicate the process for promotional reasons. Disclosing the process of faculty development can also be seen as a sign of quality assurance. 
Even though the mission statement of Laurentian's Faculty of Management recognized students' need for industry experience: "Our students engage in experiential and industry- relevant learning through internships, co-op placements, and industry consulting projects" (Laurentian University's Faculty of Management Website, n.d.), nothing is said in this mission statement about the industrial experience of faculty members. The personal pages of individual faculty members highlight research publications and academic-related experience of faculty members, but do not list the industrial experience of professors, although some professors may have had some kind of industry experience but chose not to highlight it. This could be due to an academic culture which values research-related activities, and pays little or no attention to a real life industry experience. It could also be attributed to ranking of academic institutions and the focus on research publication of institutions as a key measure.

\section{Recommendation and Conclusion}

This paper has proposed that industry skills of business faculty members can be attained through the third function in academia, namely, community engagement. Business professors, like all other professors, are required to do some community engagement activities in addition to the other two main activities of teaching and research. If faculty members are allowed to provide consulting services (paid or for free) to businesses in the community, the business college will be able to achieve two targets in one shot. The first target is engaging with their communities through professors who are providing consulting services to organizations in these communities. The second target is the development of professors by getting exposed to real life issues in these organizations as they provide their consulting services. The end result will be a win-win scenario for all stakeholders (the community, the business college, the professor, and students).

It is arguable that the focus of an academic institution can determine the shape of faculty development programs. The main focus of research universities is on research and they may not have an incentive to develop their faculty's pedagogical practices. Even universities which may not be classified as research universities are devoting more attention to research and less to other issues in higher education due to the above mentioned academic culture that values research. Professors on the tenure track need to worry about publication to realize their dream of becoming a tenured faculty member. Tenured faculty members are also required to do research, and the "publish or perish" culture is well known in academia. But even those who are doing well in research may not be as good in teaching, and may require training to master it. By understanding this reality, institutions can rationalize their faculty development programs.

Business, as an applied field, is unique due to its applied nature and due to the way it is taught. These two features can play a role in determining the shape and form of business faculty development. Establishing the link between theory and practice is important for graduating business students. One way to establish this link is through an applied pedagogical approach with the use of case studies to simulate real life situations (Rippin et al., 2002). This simulation can benefit from professors' own industry experience. Professors' experience can add a reality face to the simulated scenarios. The lack of professors' direct industry experience may not help students accurately analyze business cases. Finally, it is good to remember that honeybees are known for their honey. But one needs to be bitten by a bee to realize the agony of bee bites. 


\section{References}

1- Alfano, K. (1993). Recent strategies for faculty and staff development. Community College Review, 21(1), 68-77. http://web.ebscohost.com.ezproxy.lib.ucalgary.ca/ehost/pdfviewer/ pdfviewer?sid=285d518b-849e-4b78-9583-7ff69c95ae2a\%40sessionmgr13\&vid=5\&hid=14.

2- Askari, M., (2011). The Role of Education in Building Individual Human Capital: How Do Professionals Look at it? Available at SSRN: http://ssrn.com/abstract=2035878

3- Barnes, L. B., Christensen, C. R., \& Hansen, A. B. (1994). Teaching and the Case Method, 3rd edn (Cambridge, MA, Harvard Business School Press).

4- Becher, T. (1989) Academic tribes and territories: intellectual enquiry and the cultures of disciplines (Buckingham, Open University Press).

5- Blignaut, A. S., \& Trollip, S., R. (2003). Measuring faculty participation in asynchronous discussion forums. Journal of Education for Business, 78, 347-353.

6- Elkin, B. (2006). Construction business teaches critical work skills. Tech Directions, 66(1), 13-15.

7- Festervand, T. A., \& Tillery, K. R. (2001). Short-term study-abroad programs--a professional development tool for international business faculty. Journal of Education for Business, 77(2), 106-111. http://ezproxy.lib.ucalgary.ca:2048/login?url=http://search.proquest.com/ docview/202818997?accountid=9838.

8- Gabrielsson, J., Tell, J., \& Politis, D. (2010). Business simulation exercises in small business management education: Using principles and ideas from action learning. Action Learning: Research and Practice, 7(1), 3-16.

9- Karmas, C. (2011). School to work: Using active learning to teach business writing. USChina Education Review, 8(3), 302-316.

10- Laurentian University's Faculty of Management Website. (n.d.). Retrieved from: http://www.laurentian.ca/Laurentian/Home/Departments/Faculty+of+Management/ Our+Vision+and+Mission.htm?Laurentian_Lang=en-CA

11- Legorreta, L., Kelley, C. A., \& Sablynski, C. J. (2006). Linking faculty development to the business schools mission. Journal of Education for Business, 82(1), 3-10. http://ezproxy.lib.ucalgary.ca:2048/login?url=http://search.proquest.com/ docview/202820732? accountid=9838.

12- Lindblom-Ylänne, S., Trigwell, K., Nevgi, A., \& Ashwin, P. (2006). How approaches to teaching are affected by discipline and teaching context. Studies In Higher Education, 31(3), 285-298. http://portal.cetadl.bham.ac.uk/PRODAIT/Lists/Keith\%20Trigwell\%20 
hosted\%20forum/Attachments/3/ATI\%20and\%20discipline.pdf

13- Neumann, R., \& Becher, T. (2002) Teaching and learning in their disciplinary context: a conceptual analysis, Studies in Higher Education, 4, 405-417. http://www.ingentaconnect. com/content/routledg/cshe/2002/00000027/00000004/art00004

14- Nonaka, I. and Takeuchi, H. (1995). The Knowledge Creating Company, Oxford University Press, New York, 1995.

15- Rippin, A., Booth, C., Bowie, S., \& Jordan, J. (2002). A Complex case: Using the case study method to explore uncertainty and ambiguity in undergraduate business education. Teaching In Higher Education, 7(4), 429-41.

16- Weinzimmer, L. G., \& Manmadhan, A. (2009). Small business success metrics: The gap between theory and practice. International Journal Of Business Research, 9(7), 166-173. 